\title{
Board Director's Age and Compensation on Islamic Banking Risk Taking
}

\author{
Muhtadin Amri ${ }^{1}$, Gista Neli Mariskha ${ }^{2}$, Gea Rofiqoh Hasanah ${ }^{3}$ \\ Institut Agama Islam Negeri Ponorogo $0^{1,2,3}$ \\ \{muhtadinamri@iainponorogo.ac.id ${ }^{1}$, gistaneli8698@gmail.com², gearofiqoh@gmail.com ${ }^{3}$ \}
}

\begin{abstract}
The purpose of this study is to determine the effect of board of director's age and compensation on the level of Islamic banking risk-taking in Indonesia. The population in this study is Islamic Banking in Indonesia. Sample selection using purposive sampling method with 39 annual reports of Islamic banks in Indonesia during 2014 - 2018. This study uses multiple linear regression test. The results showed evidence that the age of directors and directors' compensation have a significant negative effect on company risktaking. Meanwhile, control variables namely company size and ROA showed no significant effect on company risk-taking. So, this study cannot prove the influence of the size of the company which is proxied by the total value of the company's assets and profitability which is proxied by the value of the ROA ratio on the level of risk-taking in Islamic banking in Indonesia.
\end{abstract}

Keywords: Age; Management Compensation; Islamic Banking Risk Taking Level

\section{Introduction}

The banking industry sector has been known as an industrial sector that is governed by very strict regulations. This cannot be separated from the risks that may be faced by the banks themselves and also the risks faced by the economy in general due to risks taken by the banking sector. The global financial crisis in 2007 - 2008 caused by too much risk taken by banks in the United States, has also drawn serious attention from regulators in the financial sector [1]. The ability to take risk becomes important for the company. Where a company must be able to assess risk according to company capacity, not too high or too low risk. So the company is cannot wrong in making the decision to invest the company's assets [2]. The Board of Directors is top management in Islamic banking. They have an important role in every company policy making. Every action taken by the company is certainly the responsibility of the director as top management. Therefore, company directors must be careful in taking every policy, especially policies that affect the company risk. In fact, not only the owner of the company has the potential to bear the risk of bankruptcy of banks, customers, creditors, and also the financial system in general also has the potential to bear the risk [3].

From the perspective of agency theory [4] the directors of companies that act as agents of the company owner and the owner of the fund, namely the customer (nasabah), are expected to 
always take actions or decisions that are beneficial to the company owner and fund owner. However, in reality, the policies taken by the board of directors, are not always beneficial for the owner and sometimes even detrimental. Among the actions that have the potential to harm the owner of the company and the owner of the fund is a policy of risk aversion and excessive risk-taking.

In Islamic law, every profit generated requires an accompanying risk. If a profit generated is not accompanied by risk, the halal status of the profit is questionable. On the other hand, if the company's management takes a risk-taking policy that is too aggressive, it will certainly make the company face the risk of loss to bankruptcy which is also large. So that a good corporate governance mechanism is needed so that the board of directors of the company can make policies, especially the right risk-taking policies, not too risk-averse or too aggressive in taking risks.

The risk-taking policy adopted by the company can be influenced by the characteristics of the company's board of directors. Characteristics like board size, non-executive directors, CEO duality, female presence, and board qualifications determine company risk-taking [5]. This indicates that the company's risk taking decisions are also determined by how how the directors risk-taking behaviour. According to [6], [7], [8], [9], [10] pointed out that the behavior of the CEO is affected by CEO characteristics, including age, experience, education, tenure, career background, gender, and duality [11]. The level of risk taken by the company's board of directors according to the results of previous studies is influenced by several factors. These factors can come from internal factors and external factors. Internal factors in question include age [12], gender, education [13]. While external factors among them are related to corporate governance such as compensation [3].

Meanwhile, studies that discuss risk-taking behavior by banks are research conducted by [14] where there is a negative relationship between age and corporate risk-taking. This research shows that older executives tend to be risk-averse. Other studies also conducted by [3] titled executive compensation and risk-taking. Using the CDS-based compensation variable, this study suggests that providing high compensation to executives can reduce financial risk-taking. The same thing was also revealed in the study of [15] where the higher the level of compensation received by the executive will have an impact on the lower risktaking.

Although there are several studies was conducted on how board of directors characteristics variable influence the level of company risk-taking. Research in this topics the islamic at the context of islamic banking, especially in Indonesia is still scarce. So, this study intends to fill the gap from the existing literature,by conducting research specifically related to how the characteristics of the board of directors of companies that act as top management can influence corporate risk-taking policies where research on this matter is still rarely done especially in the context of Islamic banking specially in Indonesia.

\section{Literature Review and Hypotheses Development}

\subsection{Risk Taking}

Decision making that is usually carried out by companies and is insecure compared to other decisions is called corporate risk-taking [16]. Also, according to [2], banking risk-taking is an action to take risks to increase bank profits and potentially cause risk. 
According to [17] risk is defined as uncertainty about something that can have a positive or negative impact.[18], mentioning risk as a threat to one's life or health.[18] states that risk is subjective because each individual has a different perception of things that are considered by other individuals as something risky. According to [19] risk-taking behavior is how individuals behave in risky situations, where this situation contains a high degree of uncertainty and the possibility of loss.

\subsection{Age of Directors and Risk Taking}

Age is defined as the length of a person's existence measured in units of time that show the same anatomical and physiological development [20]. Age classification is based on units of time, early adulthood, namely the age of 18 years to 40 years, middle adulthood between the ages of 40 years to 60 years, and mature adults over 60 years [21]. Middle adulthood is a condition in which an individual's physical abilities and skills will decrease accompanied by increased responsibilities in maintaining his career [22].

According to [14], there is a negative relationship between age and corporate risk-taking. This research shows that older executives tend to be risk-averse. Other studies also conducted by [13] put forward the hypothesis that the level of risk-taking decreases with the age of the board of directors. The results of this study found that younger executives tended to increase risk-takers compared to older executives. This is also supported by research by [23] that the average age of directors or CEOs significantly influences the size of risk used. The age of the older directors is relatively less at risk-taking company. The older the board of directors, the lower the level of risk-taking. That is because the older the board of directors, the better their ability to assess risk, maturity in thinking, and have extensive experience. Based on the description, hypothesis 1 taken in this study is:

H1: The age of directors has a negative effect on the level of Islamic Banking risk-taking

\subsection{Management Compensation and Risk Taking}

Compensation provided by a company can be in the form of financial and non-financial compensation. Financial compensation such as salaries, wages, bonuses, commissions and incentives while non-financial compensation can take the form of welfare benefits [24]. The amount of compensation provided by a company can affect the performance and motivation of directors. Where the higher the nominal compensation provided will have a positive impact on the directors' work motivation to work better. Companies become more risk-taking when incentives given to directors are intended to increase shareholder wealth [3]. However, the results of previous studies, this problem can be overcome by creating a compatible company compensation structure, so that excessive company risk can be avoided.

The study was conducted by [3] titled executive compensation and risk-taking. Using the CDS-based compensation variable, this study suggests that providing high compensation to executives can reduce financial risk-taking. The same thing was also expressed in [15] study analyzing the relationship between executive compensation and risk-taking by taking into account the state of the country's economy. There are two results from this study, 1) where when the country's economic condition is good, executives will maximize corporate risktaking and 2 ) when the economic situation is in crisis, the executive will reduce the level of risk. Overall, the higher the level of compensation received by the executive, the lower the risk-taking. Based on the description, hypothesis 2 taken in this study are: 
H2: Management compensation has a negative effect on the level of Islamic Banking risktaking

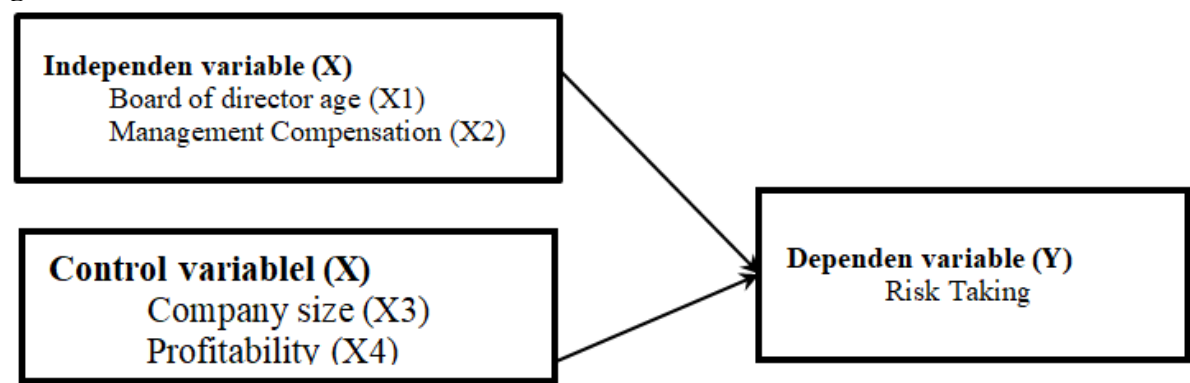

\section{Research Method}

\subsection{Sample and Data Collection}

The data used in this study are secondary data from islamic banking annual reports that are published on the website pages of each Islamic banking in Indonesia in the $2014-2018$ periods. This study uses unbalanced panel data. The study population is all Islamic banking which is a islamic banking operating in Indonesia in the 2014-2018 period. Sample selection using purposive sampling technique, namely the selection of samples with specific objectives. This study selected samples based on the following criteria:

a. Islamic commercial banks operating in Indonesia in the period $2014-2018$.

b. Sharia commercial banks that consistently publish annual reports in the period 2014 2018.

c. Bank financial statements are prepared using the rupiah currency.

d. Having data in annual reports and complete financial statements needed in research such as the date of birth of directors and the amount of compensation received by directors for one year.

e. Islamic commercial banks that have good performance (making a profit) during the study period.

f. Islamic commercial banks that posted a positive ROA in the observation period, namely $2014-2018$.

\subsection{Research Model}

The regression model used in this study is multiple regression as follows:

$$
\text { RISKit }=\beta 0+\beta 1 \text { AGEit }+\beta 2 \text { KOMPENit }+\beta 3 \text { SIZEit }+\beta 3 R O A
$$

Information:

RISKit : The level of risk taking of the company $i$ in year $t$

AGEit : Average age of company $i$ directors in year $t$

KOMPENit : The natural logarithm of total compensation received by the board of directors in one year divided by the number of directors of company $i$ in year $t$ 


$\begin{array}{ll}\text { SIZEit } & : \text { Natural logarithm total assets of company } i \text { in year } t \\ \text { ROAit } & : \text { Company profitability } i \text { in year } t \\ \varepsilon & : \text { Error term }\end{array}$

\subsection{Variable Definition and Measurement}

\section{a) Risk-Taking (RISK)}

Risk-taking behavior according to Levenson [25] is a variety of activities that make it possible to bring something new or quite dangerous that causes anxiety in most people. For measurement of risk-taking, this study uses the variable standard return on asset (ROA) for 5 years from $2010-2018$.

\section{b) $\operatorname{Age}(A G E)$}

Age is a crucial factor in the development of risk-taking behavior. Increasing the age of the individual has an impact on the different types of risk-taking behavior that is done. Some behaviors increase with age and some behaviors also decrease with age [26]. In its measurement, using the average age of the entire board of directors.

\section{c) Directors Compensation (KOMPEN)}

According to [4], compensation is a service provided by the company owner to its agents which is the company management. In reducing problems that arise due to conflicts of interest between company owners and management (agency theory), owners generally incur costs in the form of compensation given to management to be more transparent and improve the quality of their performance [27]. The proxy used to measure management compensation follows the approach taken by [28], which is the natural logarithm of the total value of management compensation received during the year divided by the number of directors of the company. The control variables used in this study are company size, profitability, and leverage. These variables are used to control the age and compensation variables of directors based on previous studies that also affect company risk-taking.

\section{d) Company Size (SIZE)}

The bank size variable is used to proxy the size of the bank and is measured by the total annual assets of the bank. Size is considered an important determinant of bank and capital risk-taking [29].

\section{e) Profitability (ROA)}

ROA (Return on Asset) is a variable used to assess a company's ability to generate profits using its resources or assets. Where high-value ROA illustrates that banks are getting better at using their assets [30]. 


\section{Results and Discussion}

Table 1. Variable Correlation Analysis

\begin{tabular}{lccccc}
\hline Correlation & $\boldsymbol{R I S K}$ & $\boldsymbol{A G E}$ & $\boldsymbol{K O M P E N}$ & $\boldsymbol{S I Z E}$ & $\boldsymbol{R O A}$ \\
\hline RISK & 1,00 & & & & \\
AGE & $-0,05$ & 1,00 & & & \\
& 0,766 & & & & \\
KOMPEN & $-0,46$ & $-0,47$ & 1,00 & & \\
\multirow{2}{*}{ SIZE } & 0,003 & 0,003 & & & \\
& $-0,27$ & $-0,47$ & 0,52 & 1,00 & \\
ROA & 0.094 & 0,002 & 0,001 & & \\
& 0,17 & $-0,01$ & $-0,22$ & $-0,31$ & 1,00 \\
& 0,304 & 0,931 & 0,182 & 0,054 & \\
\hline
\end{tabular}

Information:

$$
\begin{array}{ll}
\text { RISK } & =\text { Risk Taking Level } \\
\text { AGE } & =\text { Average age of the Board of Directors } \\
\text { KOMPEN } & =\text { Board of Directors Compensation (in millions of rupiah) } \\
\text { SIZE } & =\text { Company Size (in millions of rupiah) } \\
\text { ROA } & =\text { Company profitability }
\end{array}
$$

Table 2. Descriptive Statistics

\begin{tabular}{lccccc}
\hline \multicolumn{1}{c}{ Variable } & N & Minimum & Maximum & Mean & Std.Dev \\
\hline $\begin{array}{l}\text { Dependent Variable } \\
\text { RISK }\end{array}$ & 39 & 0,059 & 2,036 & 0,580 & 0,494 \\
& & & & & \\
Independen Variable & & & & & \\
AGE & 39 & 52 & 62 & 56 & 56 \\
KOMPEN & 39 & 840,67 & $7.276,00$ & $2.197,15$ & $1.232,76$ \\
& & & & & \\
Variabel Kontrol & 39 & 2.003 .114 & 98.341 .116 & 28.083 .637 & $27.702 .535,42$ \\
SIZE & 39 & 0,08 & 2,63 & 0,78 & 0,60 \\
ROA & & & & & \\
\hline
\end{tabular}

Information:

$$
\begin{array}{ll}
\text { RISK } & =\text { Risk Taking Level } \\
\text { AGE } & =\text { Average age of the Board of Directors } \\
\text { KOMPEN } & =\text { Board of Directors Compensation (in millions of rupiah) } \\
\text { SIZE } & =\text { Company Size (in millions of rupiah) } \\
\text { ROA } & =\text { Company profitability }
\end{array}
$$

Based on data collected from the financial statements of all Sharia Banks in Indonesia during the period 2014 - 2018 with total 14 companies or 70 observations, finally, 39 research samples were obtained that could be used. Then from these data, descriptive analysis results can be obtained to obtain an overview of the variables in the study by using the minimum value, maximum value, mean value, and standard deviation. Based on data from 39 research samples, the RISK variable which is a proxy of corporate risk-taking has an average value of 0.580 , a minimum value of 0.059 , and a maximum value of 2.036 . These results indicate that the level of risk taken by Islamic banks during the period 2014 - 2018 is fairly high with the meaning of risk-averse are 58 percent, and risk-takers are 42 percent. 
Meanwhile for the $A G E$ variable or the average age of the company's board of directors has an average value of 56, with a minimum value of 52 and a maximum value of 62 . This shows that the average age of the board of directors of Islamic Banking in Indonesia tends to be old. This can be one of the factors that makes it difficult for Islamic Banking in Indonesia to develop in Indonesia.

KOMPEN variable has a minimum value of 840.67 million rupiahs, a maximum value of 7.27 billion rupiahs, and an average value of 2.197 billion rupiahs. From these data, it can be concluded that the average annual compensation of the board of directors is Rp2,197 billion rupiah. Where the lowest directors 'compensation was Rp. 935.00 million rupiahs by Bank Victoria Syariah in 2017 and 2018. Meanwhile for the highest directors' board compensation by Bank Muamalat Indonesia amounted to Rp.7,276 billion rupiahs in 2014.

Furthermore, the control variable, SIZE, which is measured using the value of total company assets, has a minimum value of 2.0 billion rupiah, a maximum value of 98.3 billion rupiahs, and an average value of 28.0 billion rupiahs. So in the period $2014-2018$, the average total assets of the company amounted to 28.0 billion rupiah. The $R O A$ variable is used to see the extent of Islamic Banking financial performance in Indonesia. The $R O A$ variable has a minimum value of 0.08 , a maximum value of 2.63 , and an average value of 0.78 . If $R O A$ has a negative value, then a company is said to suffer losses. From the calculation results, the average ROA of Islamic Banking in Indonesia is 0.78 .

Table 3. Regression Analysis

\begin{tabular}{lccc}
\multicolumn{4}{c}{ Table 3. Regression Analysis } \\
\hline Variable & Prediction & Coefficient & Sig \\
\hline Independent Variable & - & & \\
$A G E$ & - & -0.56 & $0.003^{* * *}$ \\
KOMPEN & - & -0.39 & $0.030^{* *}$ \\
Control Variable & & & \\
SIZE & $+/-$ & -0.16 & 0.372 \\
$R O A$ & $+/-$ & -0.01 & 0.948 \\
Keterangan & & & \\
\hline
\end{tabular}

Information:

$\begin{array}{ll}\text { RISK } & =\text { Risk Taking Level } \\ \text { AGE } & =\text { Average age of the Board of Directors } \\ \text { KOMPEN } & =\text { Board of Directors Compensation (in millions of rupiah) } \\ \text { SIZE } & =\text { Company Size (in millions of rupiah) } \\ \text { ROA } & =\text { Company profitability } \\ * * * & \text { High level of significance }(1 \%), * * * \text { Significant }(5 \%), * \text { Significant moderate }(10 \%)\end{array}$

\section{a) Age of Directors on Risk Taking}

Hypothesis 1 in this study predicts that the age of directors has a negative effect on the level of risk-taking. The significance value or p-value of 0.003 with a coefficient of -0.56 in the regression analysis table shows that the results of the regression statistical testing support the hypothesis of this study. This indicates that getting older or increasing the age of directors at a bank causes a decrease in the level of risk-taking. The older the average age of directors, the more likely to avoid risk-averse. The findings in this study are in line with the research of [14] who found a negative relationship between age and corporate risk-taking. This research shows that older executives tend to limit corporate risk-taking excessively. Similarly, research 
conducted by [13], [23]prove that the age of the older directors is a relatively less risk-taking company.

The results of this study imply that directors who have a young age will be more courageous in taking risks, assuming that the higher the risk taken, the higher the profits derived by the company (high-risk high return). While older directors will be more careful in taking risks and choosing safe conditions to avoid excessive risk. From the test results, the company can be used as a measure to choose criteria for directors to manage their companies. When the company is oriented that a new policy or new strategy is important and chooses to get a high rate of return, the one who fits the criteria is young directors.

\section{b) Directors' Compensation on Risk Taking}

Hypothesis 2 in this study predicts that directors' compensation has a negative effect on the level of risk-taking. The significance value or $p$-value of 0.030 with a coefficient of -0.39 in the regression analysis table shows that the results of the regression statistical testing support the hypothesis of this study. This indicates that the compensation of directors negatively affects the company's risk-taking. The compensation of directors has a significant effect on corporate risk-taking. Where the greater the compensation received by the board of directors make the risk-taking of the company is lower. The findings in this study are in line with research conducted by [3] titled executive compensation and risk-taking. Also in line with [15] research which analyzes the relationship between executive compensation and risk-taking by taking into account the state of the country's economy. The results of this study imply that if companies provide a larger compensation for the board of directors, he board will be more cerefull to make company take riskier decision making. Compensation is one of component of the corporate governance mechanisme. So company must create an appropriate compensation mechanism so that risky company policies can still provide benefits for shareholders but at the same time do not give too much potential for bankruptcy risk.

In addition, there are also SIZE and ROA control variables. SIZE has a p-value of 0.372 with a coefficient of -0.16 . While ROA has a significant value or p-value of 0.948 with a coefficient of -0.01 . This indicates that the SIZE and ROA control variables negatively affect the company's risk-taking. But this effect is not significant. Where in the end SIZE and ROA did not affect the company's risk-taking

\section{Conclusion}

In this research, it can be seen that it is important for Islamic banking to overcome risktaking during its business activities. Islamic banking must be able to analyze what factors can influence risk-taking itself. So that the future of Islamic banking can at least control the risktaking of its business. The results showed that getting older or increasing the age of directors at a bank caused a decrease in the level of risk-taking. The older age of directors is more likely to avoid risk. Similarly, the compensation of directors who have a significant effect on corporate risk-taking. Where the greater the compensation received by the board of directors, the lower the comany risk-taking. This is in accordance with hypothesis 1 and hypothesis 2 .

There are some limitations in this study. This study only use islamic banking in Indonesia as the sample of the research, the result ini this study can be generelaized to other country or other industry. Furthermore risk taking measurement is only use deviation standard of the return on asset, future reserach can extend the measurement with another proxies. 


\section{References}

[1] L. Mairafi, S. Hassan, and S. Mohamed-arshad, “An Analysis Of The Literature On Islamic Bank Risk-Taking,” Acad. Account. Financ. Stud., vol. 22, no. February 2019, pp. 1-7, 2018.

[2] A. Wisesa, Diversitas usia dewan komisaris, profitabilitas, dan pengambilan risiko bank. Skripsi Fakultas Ekonomi dan Bisnis Universitas Airlangga, 2019.

[3] P. Bolton, "Federal Reserve Bank of New York Staff Reports: Executive Compensation and Risk Taking," New York, no. June, pp. 1-39, 2010, [Online]. Available: http://papers.ssrn.com/sol3/papers.cfm?abstract_id=1635349.

[4] M. C. Jensen and W. H. Meckling, "Theory of the firm: Managerial behavior, agency costs and ownership structure," J. financ. econ., pp. 305-360, 1976, doi: 10.1016/0304405X(76)90026-X.

[5] M. G. Abobakr and K. Elgiziry, "The Effects of Board Characteristics and Ownership Structure on the Corporate Financial Leverage," Account. Financ. Res., 2015, doi: 10.5430/afr.v5n1p1.

[6] W. R. Knechel, D. S. Sharma, and V. D. Sharma, "Non-Audit Services and Knowledge Spillovers: Evidence from New Zealand," J. Bus. Financ. Account., 2012, doi: 10.1111/j.1468-5957.2011.02268.x.

[7] W. R. Knechel, "William W. Cooper 1914-2012," Audit. A J. Pract. Theory, 2012, doi: 10.2308/ajpt-10310.

[8] W. N. Wan-Hussin and H. M. Bamahros, "Do investment in and the sourcing arrangement of the internal audit function affect audit delay?," J. Contemp. Account. Econ., 2013, doi: 10.1016/j.jcae.2012.08.001.

[9] M. N. Mohamad-Nor, R. Shafie, and W. N. Wan-Hussin, "Corporate governance and audit report lag in Malaysia," Asian Acad. Manag. J. Account. Financ., 2010.

[10] J. Al-Ajmi, "Audit and reporting delays: Evidence from an emerging market," $A d v$. Account., 2008, doi: 10.1016/j.adiac.2008.08.002.

[11] N. V. Khuong and N. T. X. Vy, "CEO Characteristics and Timeliness of Financial Reporting of Vietnamese Listed Companies," VNU J. Sci. Econ. Bus., 2017, doi: 10.25073/2588-1108/vnueab.4127.

[12] L. M. Firdaus and D. Adhariani, "Board of directors' gender, managerial ownership and corporate risk-taking: Evidence from Indonesia," Pertanika J. Soc. Sci. Humanit., vol. 25, no. November, pp. 281-297, 2017.

[13] A. N. Berger, T. K. Kick, and K. Schaeck, "Executive Board Composition and Bank Risk Taking," SSRN Electron. J., no. 03, pp. 1-71, 2012, doi: 10.2139/ssrn.2007021.

[14] J. Peltomaki, S. Swidler, and S. Vahamaa, "Age, Gender, and Risk-Taking : Evidence From the S \& P 1500 Executives," no. September, pp. 1-56, 2019.

[15] A. Raviv and E. Sisli-ciamarra, "Executive Compensation, Risk Taking and The State of The Economy," vol. 1, no. 781, pp. 1-56, 2012.

[16] R. M. Nurhidayat and R. Rokhim, "Corruption and Government Intervention on Bank Risk-Taking: Cases of Asian Countries," J. Din. Manaj., vol. 9, no. 2, pp. 228-237, 2018, doi: 10.15294/jdm.v9i2.15951.

[17] D. Hillson and R. Murray, Understanding and Managing Risk Attitude, Webster. 2005.

[18] J. F. Yates, Risk Taking Behaviour. Chicester: Wiley, 1992.

[19] J. F. Yates, Risk Taking Behaviour. New York: J Wiley, 1994.

[20] D. Nuswantari, Kamus Kedokteran Dorland Edisi 25. Jakarta: EGC, 1998.

[21] E. B. Hurlock, Psikologi Perkembangan: Suatu Pendekatan Sepanjang Rentang 
Kehidupan. Jakarta: Erlangga, 2002.

[22] S. Kusumastuti, Supatmi, and P. Sastra, "Pengaruh Board Diversity Terhadap Nilai Perusahaan Dalam Perspektif Corporate Governance," J. Akunt. dan Keuang., vol. 9, no. 2, pp. 88-98, 2007, doi: 10.9744/jak.9.2.pp.88-98.

[23] E. Elsaid and N. D. Ursel, "CEO succession, demographics and risk taking," Chem. ..., pp. $1-20, \quad$ 2009, [Online]. Available: http://onlinelibrary.wiley.com/doi/10.1002/cbdv.200490137/abstract.

[24] M. . Dr. Kasmir M.M., "Manajemen Sumber Daya Manusia (Teori dan Praktik)," in Manajemen Sumber Daya Manusia (Teori dan Praktik), Depok: PT RajaGrafindo Persada, 2019, pp. 240-250.

[25] R. S. Rachmahana, "Dorongan Mencari Sensasi dan Perilaku Pengambilan Resiko Pada Mahasiswa," Psikologika J. Pemikir. dan Penelit. Psikol., 2002, doi: 10.20885/psikologika.vol7.iss14.art5.

[26] M. Ritcher, Risk behavior in adolescence, patterns, determinants, and consequences. Germany: Springer Fachmedien, 2010.

[27] P. McColgan, "Agency theory and corporate governance: a review of the literature from a UK perspective," Dep. Account. Financ. Univ. Strat., 2001.

[28] C. S. Armstrong, J. L. Blouin, and D. F. Larcker, "The incentives for tax planning," J. Account. Econ., pp. 391-411, 2012, doi: 10.1016/j.jacceco.2011.04.001.

[29] M. M. RAHMAN, C. ZHENG, and B. N. ASHRAF, "Bank Size, Risk-taking and Capital Regulation in Bangladesh," Eurasian J. Bus. Econ., vol. 8, no. 15, pp. 95-114, 2015, doi: 10.17015/ejbe.2015.015.05.

[30] S. Haryanto, "Profitability Identification of National Banking Through Credit, Capital, Capital Structure, Efficiency, and Risk Level," J. Din. Manaj., vol. 7, no. 1, pp. 11-21, 2016, doi: 10.15294/jdm.v7i1.5749. 